\title{
KARAKTERISASI BIOPLASTIK DARI K-KARAGENAN EUCHEUMA COTTONII TERPLASTISASI BERPENGUAT NANOSELULOSA
}

\author{
Syahnya Alifia Nurhabibah ${ }^{1}$, Wida Banar Kusumaningrum², \\ 1) Teknik Bioproses, Universitas Brawijaya \\ Jl. Veteran, Ketawanggede, Kec. Lowokwaru, Kota Malang, Jawa Timur \\ 2) Biomaterial, Lembaga IImu Pengetahuan Indonesia (LIPI) \\ Jl. Raya Jakarta-Bogor No. KM 48, Cibinong, Bogor, Jawa Barat \\ E-mail: Syahnyahabibah@gmail.com
}

Received : 1 Maret 2021; revised : 31 Maret 2021; accepted : 23 Juni 2021

\begin{abstract}
ABSTRAK
KARAKTERISASI BIOPLASTIK DARI K-KARAGENAN EUCHEUMACOTTONII TERPLASTISASI BERPENGUAT NANOSELULOSA. Nanoselulosa dapat digunakan sebagai penguat bioplastik karena memiliki kelebihan yaitu dapat meningkatkan kekuatan, kekakuan, ketangguhan, dan perbaikkan sifat permeabilitas. Penelitian ini bertujuan untuk mengetahui pengaruh penambahan nanoselulosa terhadap karakteristik bioplastik karagenan Eucheuma Cottonii terplastisasi dan memperbaiki sifat dari bioplastik yang belum bisa diaplikasikan. Penambahan nanoselulosa dilakukan pada konsentrasi 0,5\%: 1\%: 2,5\%: 5\%, 7,5\% dan 10\%, dengan mencampurnya pada K-Karagenan Eucheuma Cottonii 3\% dan komposisi gliserol 35\%. Hasil analisis sidik ragam (ANOVA) menunjukkan bahwa pemberian perlakuan nanoselulosa pada berbagai konsentrasi tidak memiliki pengaruh terhadap karakteristik sifat bioplastik seperti ketebalan (Nanoselulosa 10\%;0,155 mm), water solubility (Nanoselulosa $1 \% ; 61,285 \%$ ), dan water vapor transmission rate (WVTR) (Nanoselulosa 10\%;36.397,729 $\mathrm{g} / \mathrm{m}^{2} /$ day). Namun, berpengaruh nyata terhadap karakteristik sifat bioplastik seperti kadar air (Nanoselulosa 0,5\% ; 19,656\%), kuat tarik (Nanoselulosa 2,5\%; 93,120 KgF/cm² atau 9,132 Mpa), \%-perpanjangan (Nanoselulosa $7,5 \%$; 64,625\%), modulus young (Nanoselulosa 0,5\% ; 37,222 Mpa atau 0,037222 Gpa), dan biodegradasi (Nanoselulosa $0,5 \%$; 8\% selama 25 hari). Hasil karakteristik tersebut telah sesuai dengan Japanese International Standards (JIS 2-1707) dan referensi yang ada, kecuali water solubility dan water vapor transmission rate (WVTR).
\end{abstract}

Kata kunci : Bioplastik, Nanoselulosa, K-Karagenan Eucheuma Cottonii

\begin{abstract}
CHARACTERISTICS OF K-CARAGEENAN EUCHEUMA COTTONII BIOPLASTIC REINFORCED WITH NANOCELLULOSE. Nanocellulose can be used as bioplastic reinforcement because it has the advantage that it can increase strength, stiffness, toughness, and improve permeability. This study aims to determine the effect of the addition of nanocellulose on the characteristics of plasticized Eucheuma Cottonii carrageenan and to improve the properties of bioplastics that cannot be applied. The addition of nanocellulose was carried out at a concentration of 0.5\%: 1\%: 2.5\%: 5\%, 7.5\% and 10\%, by mixing it in K-Carrageenan Eucheuma Cottonii 3\% and glycerol composition of $35 \%$. The results of analysis of variance (ANOVA) showed that giving nanocellulose treatment at various concentrations had no effect on the characteristics of bioplastic properties such as thickness $(10 \%$ Nanocellulose; $0.155 \mathrm{~mm}$ ), water solubility (1\% Nanocellulose; $61.285 \%)$, and water vapor transmission rate ( WVTR) (Nanocellulose 10\%; 36,397,729 $\mathrm{g} / \mathrm{m}^{2} /$ day). However, a significant effect on the characteristics of bioplastic properties such as moisture content (Nanocellulose 0.5\%; 19.656\%), tensile strength (Nanocellulose $2.5 \%$; $93.120 \mathrm{KgF} / \mathrm{cm}^{2}$ or $9.132 \mathrm{Mpa}$ ), \% -length (7.5\% Nanocellulose; 64.625\%), modulus young (Nanocellulose 0.5\%; 37.222 Mpa or $0.037222 \mathrm{Gpa}$ ), and biodegradation (Nanocellulose $0.5 \% ; 8 \%$ for 25 days). The results of these characteristics are in accordance with existing international and national standards, except for water solubility and water vapor transmission rate (WVTR).
\end{abstract}

Key words : Bioplastic, Nanocellulose, K-Carrageenan Eucheuma Cottonii

\section{PENDAHULUAN}

Plastik saat ini masih mendominasi sebagai kemasan berbagai produk makanan di Indonesia. Menurut data Kementrian Lingkungan Hidup tahun 2019, produksi plastik mencapai 66-67 ton / tahun (Permana, 2019). Produk plastik kemasan konvensional yang saat ini beredar di pasaran berbahan dasar polimer turunan minyak bumi seperti PE (Polyethelene), PVC (Polyvynil Chloride) dan EVOH (Ethylene Vinyl Alcohol) (Carbone et al., 2018). Keunggulan kemasan 
plastik antara lain ringan, fleksibel, multifungsi, kuat, tidak rapuh, bersifat termoplastis, mudah untuk dibentuk, colorful, murah serta berperan sebagai isolator panas dan listrik yang baik. Namun demikian, plastik konvensional memiliki berbagai kekurangan, yaitu kemungkinan terjadinya migrasi monomer dari plastik ke makanan terutama pada penyimpanan jangka waktu lama dan suhu tinggi yang berbahaya untuk kesehatan (Andrieti, 2018), dan tidak dapat terdegradasi oleh alam yang menyebabkan pencemaran lingkungan (Panjaitan et al., 2017). Oleh karena itu, diperlukan alternatif pengganti plastik yang lebih ramah lingkungan dengan sifatsifat yang sebanding dengan plastik konvensional. Bioplastik merupakan salah satu pengganti kemasan makanan yang memiliki keunggulan tidak mengandung zat pencemar berbahaya, murah, kuat, ringan, stabil, mudah diproduksi, dan mudah terdegradasi (Wijayanti et al., 2016).

Bioplastik merupakan plastik dengan bahan dasar polimer organik alami (biopolimer) yang berasal dari senyawa tumbuhan seperti karagenan, selulosa, pati dan lignin (Rajandran et al., 2012). Salah satu biopolimer yang potensial saat ini di Indonesia adalah k-karagenan Eucheuma Cottonii. Berdasarkan data statistik dari Direktorat Jendral Perikanan Budidaya, produksi pertumbuhan rumput laut nasional meningkat dengan rata-rata sekitar $2,92 \%$ dalam kurun waktu 2020 - 2024, sementara itu, khususnya pada tahun 2020 produksi rumput laut nasional akan mencapai 10,99 juta ton (Kementrian Kelautan dan Perikanan, 2020). Rumput laut Eucheuma cottonii diperkirakan memiliki potensi nilai ekonomi di Indonesia mencapai 10 miliar dolar AS per tahun (Kementrian Kelautan dan Perikanan, 2020). Hal ini dikarenakan rumput laut bersifat terbarukan, sangat mudah dikembangkan, memiliki masa tanam hingga panen (budidaya) yang cukup singkat, dapat meningkatkan viskositas, dan mengandung berbagai polimer yang tesusun atas karagenan. Karagenan adalah kelompok polisakarida galaktosa yang diekstrak dari beberapa rumput laut merah atau alga merah (Rhodophyceae) (Distantina et al., 2010). Beberapa studi pemanfaatan karagenan yang diisolasi dari E.cottonii telah dilakukan baik dengan kemurnian rendah (semi refined) maupun kemurnian tinggi (refined). Komposisi karagenan pada bioplastik beragam mulai dari $0,6 \%$ sampai dengan 2\% (b/v) (Fransiska et al., 2018; Giyatmi et al., 2020; Hamid et al., 2018; Harumarani et al., 2016; Khoirunnisa et al., 2018; Maryuni et al., 2018; Sedayu, 2020). Namun komposisi optimum yang menghasilkan bioplastik karagenan dengan sifat fisik dan mekanik terbaik adalah komposisi 2\% (b/v) (Maryuni et al., 2018). Kehadiran pemlastis pada bioplastik sangat berperan dalam peningkatan sifat mekanis terutama pada penambahan panjang (elongation at break) yang memungkinkan bioplastik menjadi lebih fleksibel. Pemlastis dengan berat molekul rendah digunakan pada bioplastik karagenan seperti gliserol (Hamid et al., 2018; Harumarani et al., 2016; Khoirunnisa et al., 2018; Sedayu, 2020), sorbitol (Maryuni et al., 2018), dan polietilen glikol (Fransiska et al., 2018; Giyatmi et al., 2020). Studi yang dilakukan oleh (Fransiska et al., 2018) melaporkan bahwa penambahan polietilen glikol dapat meningkatkan penambahan panjang sampai pada komposisi $4 \%$ (b/v) namun menurunkan kekuatan tarik seiring dengan penambahan komposisi. Oleh karena itu, pada penelitian ini pemlastis yang digunakan adalah gliserol yang aman digunakan untuk produk kemasan makanan dan juga umum digunakan. Komposisi gliserol bervariasi dari 10\% sampai dengan 40\% (b/b) (B. Darni et al., 2014; Hamid et al., 2018; Khoirunnisa et al., 2018; Sedayu, 2020). Komposisi optimum gliserol berbeda-beda tergantung dari sumber bahan karagenan yang digunakan.

Kemasan makanan berbasis bioplastik memiliki keterbatasan dibandingkan dengan plastik konvensional diantaranya karena sifat mekanis, ketahanan panas, dan sifat pembatas yang rendah. Berbagai upaya dikembangkan untuk memperbaiki sifat-sifat tersebut dengan penambahan aditif baik organik maupun inorganik. Salah satu upayanya adalah dengan penambahan nanoselulosa. Nanoselulosa dengan ukuran diameter kurang dari 100 nm sangat berpotensi meningkatkan kekuatan antar molekul serat dengan matrik serta meningkatkan sifat pembatas gas dan uap air (Azeredo et al., 2017). Berdasarkan morfologinya, nanoselulosa berupa selulosa nanokristal (CNC) (rod like) dengan morfologi seperti jarum dan selulosa nanofibril (CNF) dengan morfologi seperti benang (web-like) dengan aspek rasio tinggi (Joonobi et al., 2015). Penambahan 4\% (b/b) CNC pada bioplastik karagenan mampu meningkatkan storage modulus $29 \%$ dan juga ketahanan panas dengan peningkatan Tonset mencapai $40{ }^{\circ} \mathrm{C}$ dibandingkan tanpa penambahan CNC (Zakuwan et al., 2019). (Sedayu, 2020) melaporkan peningkatan kekuatan tarik bioplastik karagenan mencapai $21,6 \%$ dengan penambahan $3 \%(b / b)$ CNF namun terjadi penurunan penambahan panjang, selain itu juga terjadi penurunan water vapor permeability sekitar $12,5 \%$ dibandingkan dengan tanpa penambahan CNF. Pada bioplastik berbasis polivil alkohol, CNF yang diisolasi dari serat nanas memberikan pengaruh positif pada peningkatan kekuatan tarik dan penambahan panjang pada komposisi CNF 40\% (b/b) (Iriani et al., 2015). Sementara itu, menurut (Widyaningrum et al., 2020) komposisi selulosa 
terfibrilasi lebih dari 1\% (b/b) akan menurunkan sifat mekanis bioplastik pati/polivinil alkohol.

Penelitian ini memanfaatkan nanoselulosa yang diisolasi dari serat batang sorgum. Batang sorgum memiliki kandungan selulosa sekitar $57,99 \%$ sebanding dengan serat alam komersial seperti flex, hemp, dan kelapa (Kartini \& Pandebesie, 2016). Isolasi nanoselulosa dilakukan secara mekanis menggunakan ultrafine friction grinder dengan tujuan memperoleh morfologi serat terfibrilasi dengan aspek rasio tinggi, CNF. Studi terkait pengaruh CNF komersial pada bioplastik berbasis karagenan hanya dilakukan oleh (Sedayu, 2020). Sejauh pengamatan penulis, belum ada studi terkait bioplastik karagenan dengan penguat CNF dari serat batang sorgum yang diisolasi dengan ultrafine friction grinder. Penelitian ini bertujuan untuk mengetahui pengaruh penambahan CNF pada berbagai komposisi terhadap karakteristik fisik dan mekanis bioplastik karagenan Eucheuma Cottonii terplastisasi . Pemanfaatan karagenan sebagai matrik dan nanoselulosa yang bersumber dari sorgum diharapkan mampu memberikan peningkatan nilai tambah komponen lokal dan berkontribusi pada pembangunan rendah karbon serta ekonomi berkelanjutan terutama pada kemasan makanan ramah lingkungan.

\section{BAHAN DAN METODE}

\section{Bahan}

Bahan yang digunakan yaitu Karagenan Eucheuma Cottonii jenis KAPPA dengan merek Poly Lab yang diproduksi oleh PT. Labo Chemi Indonesia, pulp batang sorgum yang belum diputihkan, Hidrogen Peroksida $\left(\mathrm{H}_{2} \mathrm{O}_{2}\right) 30 \%$ pure analysis dengan merek Merck Indonesia, Natrium Hidroksida (NaOH) teknis, Gliserol dengan merek Schuchardt $\mathrm{OHG}$, aquades, dan EM4 pertanian yang diproduksi oleh PT. Songgolangit Persada.

\section{Metode}

Penelitian dilakukan di laboratorium bioproduk terintegrasi (iLaB) Pusat Penelitian Biomaterial LIPI Cibinong. Tahapan penelitian meliputi pembuatan nanoselulosa secara mekanis, pembuatan bioplastik dengan penambahan nanoselulosa dan karakterisasi serta analisis data bioplastik.

\section{Pembuatan Nanoselulosa Secara Mekanis \\ Tahapan yang dilakukan yaitu pulp basah} dicampurkan dengan sejumlah aquades. Kemudian, campuran tersebut diteteskan dengan $\mathrm{NaOH}$ sampai $\mathrm{pH}$ menunjukkan kondisi basa $(\mathrm{pH}$ 9). Lalu, ditambahakan $\mathrm{H}_{2} \mathrm{O}_{2} \quad 30 \%$ pada campuran dan menutup campuran tersebut dengan alumunium foil. Campuran tersebut kemudian dimasukkan kedalam water bath dengan suhu $80^{\circ} \mathrm{C}$ selama 1 jam, dan dilakukan pengadukan berulang setiap 15 menit. Setelah selesai, campuran tersebut dicuci dengan aquades sampai bersih. Dilakukan pengulangan proses sampai pulp berubah warna menjadi putih. Hasil bleaching kemudian disimpan pada lemari es dengan suhu $4^{\circ} \mathrm{C}$.

Pembuatan nanoselulosa secara mekanis mengunakan alat ultrafine friction grinding, masuko sangyo. Pertama-tama, selulosa dilarutkan dalam aquades. Kemudian, larutan suspensi selulosa dengan konsentrasi 2,5\% dilewatkan pada sebuah hooper diantara dua piringan yang umumnya terbuat dari batu tahan aus dengan kecepatan rata-rata $1.500 \mathrm{rpm}$. Proses fibrilasi terjadi karena adanya kontak antara piringan batu dan serat yang menyebabkan tingginya gaya gesek dan tekanan pada serat. Derajat fibrilasi dapat diatur dengan cara mengatur lebar celah antar piringan serta siklus suspensi bahan yang melewati mesin penggiling, degan gap -3, gap -5, gap -7, gap -9. gap -11, gap -13 dan gap -15. Proses sirkulasi pada setiap gap dilakukan sebanyak 4 sampai 5 kali hingga diperoleh suspensi nanoselulosa yang kental. Suspensi disimpan pada suhu $4{ }^{\circ} \mathrm{C}$ sampai nanoselulosa digunakan.

\section{Pembuatan Bioplastik Dengan Penambahan Nanoselulosa}

Tahapan proses yang dilakukan pada proses ini adalah mencampurkan nanoselulosa dan aquades, masing-masing pada konsentrasi sebesar 0,5\%: 1\%: 2,5\%: 5\%, 7,5\% dan 10\% (b/b). Kemudian, mencampurkan K-Karagenan Eucheuma Cottonii pada konsentrasi 3\% (b/v). Kkaragenan dan nanoselulosa dicampurkan dengan kecepatan putar 250 rpm pada suhu $80^{\circ} \mathrm{C}$ selama 60 menit. Kemudian, gliserol sebanyak 35\% (b/b) ditambahkan ke dalam campuran dan diaduk selama 15 menit. Selanjutnya, campuran yang telah homogen dituangkan ke dalam cetakan plat kaca, kemudian dikeringkan di dalam oven pada suhu $50{ }^{\circ} \mathrm{C}$ selama 24 jam. Bioplastik yang sudah kering kemudian dilepaskan dari cetakan dan selanjutnya dilakukan pengujian karakteristiknya. Karakterisasi akan dilakukan pada sampel pada Tabel 1.

Tabel 1. Kode Sampel

\begin{tabular}{|l|l|}
\hline \multicolumn{1}{|c|}{ Kode } & \multicolumn{1}{c|}{ Sampel } \\
\hline K3 & Karagenan 3\% \\
\hline K3 G35 & Karagenan 3\% Gliserol 35\% \\
\hline K3 G35 NS 0,5 & $\begin{array}{l}\text { Karagenan 3\% Gliserol 35\% } \\
\text { Nanoselulosa 0,5\% }\end{array}$ \\
\hline K3 G35 NS 1 & $\begin{array}{l}\text { Karagenan 3\% Gliserol 35\% } \\
\text { Nanoselulosa 1\% }\end{array}$ \\
\hline K3 G35 NS 2,5 & $\begin{array}{l}\text { Karagenan 3\% Gliserol 35\% } \\
\text { Nanoselulosa 2,5\% }\end{array}$ \\
\hline
\end{tabular}




\begin{tabular}{|l|l|}
\hline K3 G35 NS 5 & $\begin{array}{l}\text { Karagenan 3\% Gliserol 35\% } \\
\text { Nanoselulosa 5\% }\end{array}$ \\
\hline K3 G35 NS 7,5 & $\begin{array}{l}\text { Karagenan 3\% Gliserol 35\% } \\
\text { Nanoselulosa 7,5\% }\end{array}$ \\
\hline K3 G15 NS 10 & $\begin{array}{l}\text { Karagenan 3\% Gliserol 15\% } \\
\text { Nanoselulosa 10\% }\end{array}$ \\
\hline
\end{tabular}

\section{Karakterisasi Bioplastik \& Analisis Data}

\section{Scanning Electron Microscopy (SEM)}

Karakterisasi SEM hanya dilakukan pada nanoselulosa, dengan menggunakan alat FESEM Thermo Scientific Quattro S. Pengujian sampel dilakukan dalam keadaan basah (wet). Perbesaran yang digunakan sebesar 15.000 sampai dengan 150.000 kali, dengan energi elektron berkisar antara $15 \mathrm{kV}$ sampai $30 \mathrm{kV}$.

\section{Ketebalan}

Uji ketebalan, dilakukan dengan mengikuti metode microcal messmer (ASTM D1005). Ketebalan bioplastik diukur menggunakan alat Electronic Digital Calliper dengan ketelitian 0,01 $\mathrm{mm}$. Pengukuran bioplastik dilakukan pengulangan sebanyak tiga kali (triplo) pada lima titik yang berbeda yaitu bagian setiap sudut dan tengah bioplastik. Nilai ketebalan bioplastik didapatkan dengan menggunakan rumus pada persamaan 1 .

Ketebalan Rerata $=\frac{\text { Sisi } 1+\text { Sisi } 2+\text { Sisi } 3+\text { Sisi } 4+\text { Sisi } 5}{5}$

\section{Water Solubility}

Uji kelarutan dilakukan dengan prosedur yang telah dilakukan oleh (Widyaningsih, 2012), dengan cara memotong sampel dengan ukuran 3 $\mathrm{cm}$ x $3 \mathrm{~cm}$, kemudian diletakan kedalam cawan petri yang terlebih dahulu telah ditimbang beratnya. Kemudian sampel bioplastik dimasukkan ke dalam oven dengan suhu $100^{\circ} \mathrm{C}$ selama 30 menit, lalu timbang berat sampel kering sebagai berat kering awal (Wo). Sampel kemudian direndam selama 24 jam. Sampel yang tidak terlarut dalam larutan diangkat dan dikeringkan dalam oven $100{ }^{\circ} \mathrm{C}$ selama 2 jam. Sampel ditimbang kembali sebagai berat sampel setelah perendaman (W1). Persentase kelarutan sampel dalam air dihitung dengan persamaan 2 .

$$
\mathrm{S}=\frac{W o-W 1}{W o} \times 100 \% \text {... }
$$

\section{Kadar Air}

Pengujian kadar air dilakukan dengan memodifikasi prosedur yang telah dilakukan oleh (AOAC, 1990). Prosedur yang dilakukan dengan cara menimbang berat cawan alumunium kosong dengan timbangan analitik. Dimasukkan sampel ke dalam cawan alumunium dan ditimbang $(X)$. Cawan yang berisi sampel dikeringkan dalam oven $100{ }^{\circ} \mathrm{C}$ selama 24 jam sampai tercapai bobot konstan. Sampel kemudian ditimbang $(Y)$. Perhitungan kadar air dilakukan dengan menggunakan persamaan 3 .

$$
\text { Kadar Air }=\frac{X-Y}{X} \times 100 \%
$$

\section{Water Vapor Transmission Rate (WVTR)}

Pengujian laju transmisi uap air menggunakan standar ASTM E-96, dengan ukuran pengujian film sebesar $5 \mathrm{~cm} \times 5 \mathrm{~cm}$. Lajur transmisi uap air (WVTR) ditentukan secara gravimetri dengan menggunakan metode yang telah dilakukan oleh (Gutari, 2019), yang menentukan nilai Water Vapour Transmition Rate (WVTR) dan Water Vapour Permeability (WVP) dengan metode cawan. Cawan petri yang telah diisi air ditutup dengan alumunium foil sesuai ukuran cawan. Sebelumnya, bagian tengah kertas alumunium foil dilubangi seluas 10\% dari luas cawan petri (d) dan ditempeli film $(5 \mathrm{~cm} \times 5$ $\mathrm{cm}$ ) yang akan diukur nilai permeabilitas uap airnya (WVP). Kertas alumunium foil direkatkan dengan karet pada cawan petri. Cawan yang berisi sampel (R1 dengan RH 100\%) kemudian ditimbang dan dimasukkan ke dalam oven pada suhu $37 \pm 0.5{ }^{\circ} \mathrm{C}(\mathrm{R} 2)$ dengan tekanan udara jenuh pada suhu $37{ }^{\circ} \mathrm{C}$ sebesar $6266.134 \mathrm{~Pa}$. Berat cawan dicatat setiap 1 jam sebanyak 8 kali ulangan. Massa air yang hilang dilihat berdasarkan fungsi waktu sampai keadaan tunak tercapai. Selanjutnya, data yang diperoleh akan dianalisis dengan membuat persamaan regresi linier, dan ditentukan slope-nya. Laju transmisi uap air ditentukan dengan persamaan 4 dan 5 .

$$
\begin{gathered}
\text { WVTR }=\frac{\text { Slope Kenaikan Berat Cawan }\left(\frac{g}{j a m}\right)}{\text { Luas Permukaan Film }\left(m^{2}\right)} \ldots \\
\mathrm{WVP}=\frac{\text { WVTR } x d}{S x(R 1-R 2)} \times 100 \% \ldots(5)
\end{gathered}
$$

\section{Universal Attenuated Total Reflectance Fourier Transform Infra-Red (UATR-FTIR)}

Analisis komponen kimia menggunakan UATR-FTIR Spectrum Two Perkin Elmer. Sampel diletakkan pada reflektor kemudian pemindaian dilakukan pada pajang gelombang 4000 sampai dengan $400 \mathrm{~cm}^{-1}$. Pengulangan pemindaian sebanyak 16 kali.

\section{Kuat Tarik, \% Pemanjangan, Dan Modulus Elastisitas}

Sampel film bioplastik diuji sesuai dengan standar ASTM-D882-75b dengan rectangular cross section $25 \mathrm{~mm}$, grip section $25 \mathrm{~mm}$ dan gauge length $50 \mathrm{~mm}$. Pengujian dilakukan dengan cross head speed $20 \mathrm{~mm} \cdot \mathrm{min}^{-1}$. Sampel kemudian dipotong sesuai standar sebesar 2,5 
cm x $10 \mathrm{~cm}$ (Rifaldi et al., 2017). Dalam satu kali running didapatkan data berupa Kua Tarik, \%Elongation, dan Modulus Young. Perhitungan dapat dilakukan dengan menggunakan rumus pada persamaan 6,7 , dan 8 .

$$
\begin{gathered}
\text { Tensile Strength }(M p a)=\frac{F(N)}{A(m)} \ldots(6) \\
\% \text { Elongation }=\frac{\text { Panjang putus }(\mathrm{cm})-\text { panjang awal }(\mathrm{cm})}{\text { Panjang awal }(\mathrm{cm})} \times 100 \% \ldots(7) \\
\text { Modulus Young }(M p a)=\frac{\text { Tensile Strength }(\text { Mpa })}{(\%-\text { elongation: } 100)} \ldots(8)
\end{gathered}
$$

\section{Biodegradabelitas}

Uji biodegradasi dilakukan pada kondisi aerobik dengan bantuan bakteri. Effective Microorganism 4 (EM4) mengandung bakteri fermentasi dari genus Lactobacillus dan Saccharomyces, jamur fermentasi, actinomycetes yaitu bakteri fotosintetik, bakteri pelarut fosfat, ragi, bakteri penambat $\mathrm{N}$, penghasil fitohormon, serta perombak bahan organik (selulolitik dan lignolitik). Metode ini dilakukan dengan menggunakan prinsip (ASTM G21-2015) (Sumartono et al., 2015). Sampel bioplastik dipotong dengan ukuran $8 \mathrm{~cm} \times 2 \mathrm{~cm}$ berjumlah 3 buah, kemudian dihitung massa sampelnya. Sampel dimasukkan di dalam EM4 yang terkontrol sifat fisik dan kimiawinya kemudian dihitung fraksi berat residual dari sampel dalam tiap satuan waktu (Wo) dalam setiap kurun waktu 5 hari (W) dengan waktu uji selama 25 hari. Perhitungan dilakukan dengan rumus pada persamaan 9 dan 10 .

$$
\% \text { Kehilangan Berat }=\frac{W 0-W}{W 0} \times 100 \% \ldots
$$

$$
\text { Laju Degradabelitas }=\frac{\% \text { Kehilangan Berat }}{\text { Waktu Uji }} \ldots
$$

\section{Analisa Data}

Rancangan penelitian yang dilakukan adalah dengan menggunakan metode Rancangan Acak Lengkap (RAL) dengan tujuan mencari karakteristiki nanoselulosa terbaik dari setiap uji yang telah dilakukan, kemudian apabila terdapat perbedaan yang nyata dilakukan pengujian lanjut (post-hoc) Duncan's Multiple Range Test (DMRT) dengan selang kepercayaan $5 \%$ untuk pengambilan keputusan perlakuan terbaik dari masing-masing rancangan percobaan. Faktor yang dipilih dalam penelitian ini adalah variasi konsentrasi nanoselulosa dengan 6 level (0,5\%; 1\%; 2,5\%; 5\%; 7,5\%;10\%). Perlakuan dilakukan dengan 18 satuan percobaan.

\section{HASIL DAN PEMBAHASAN}

\section{Scanning electron microscopy (SEM)}

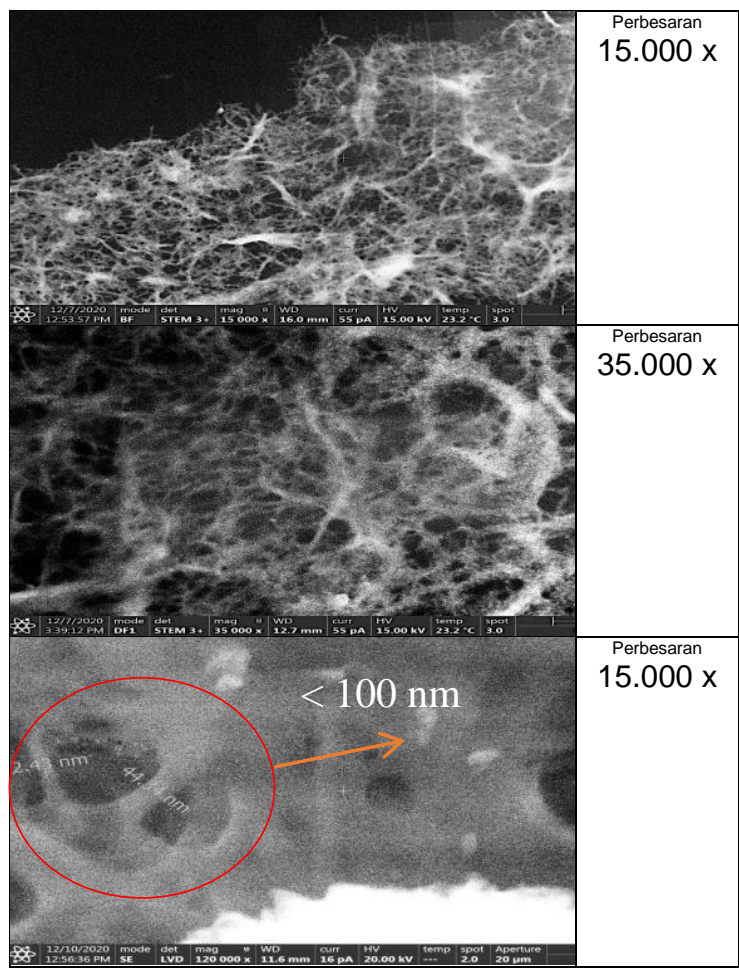

Gambar 1. Hasil SEM Nanoselulosa Batang Sorgum

Pengujian SEM akan menunjukkan morfologi nanoselulosa yang berguna untuk menentukan kesesuaian struktur permukaan sampel. Stabilitas suspensi nanoselulosa mendapatkan hasil yang lebih baik dengan perlakuan grinding pada gap -15, seperti pada Gambar 2. Gugus hidroksil yang semakin terekspos pada selulosa menyebabkan ikatan hidrogen yang lebih kuat dengan pelarut air sehingga stabilitas nanoselulosa menjadi meningkat. Gambar 1 menunjukkan bahwa nanoselulosa memiliki struktur jaringan berlapis lapis (web-like) dimana diameter serat pada skala nanometer dengan panjang masih dalam skala mikrometer sehingga diperoleh nanoselulosa dengan aspek rasio tinggi yang bermanfaat sebagai penguat pada bioplastik. Semakin kecil ukuran serat selulosa akan memberikan daya rekat antarmuka yang lebih baik antara serat dan matriks (Winarno \& Fernandez, 2010). Menurut (Yulianto et al., 2020) nanoselulosa dengan ukuran kecil akan memberikan luas permukaan yang lebih besar untuk ikatan serat dan matriks bioplastik.

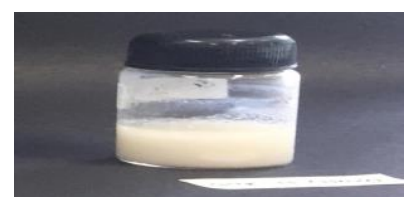

Gambar 2. Stabilitas Suspensi Nanoselulosa pada gap -15 


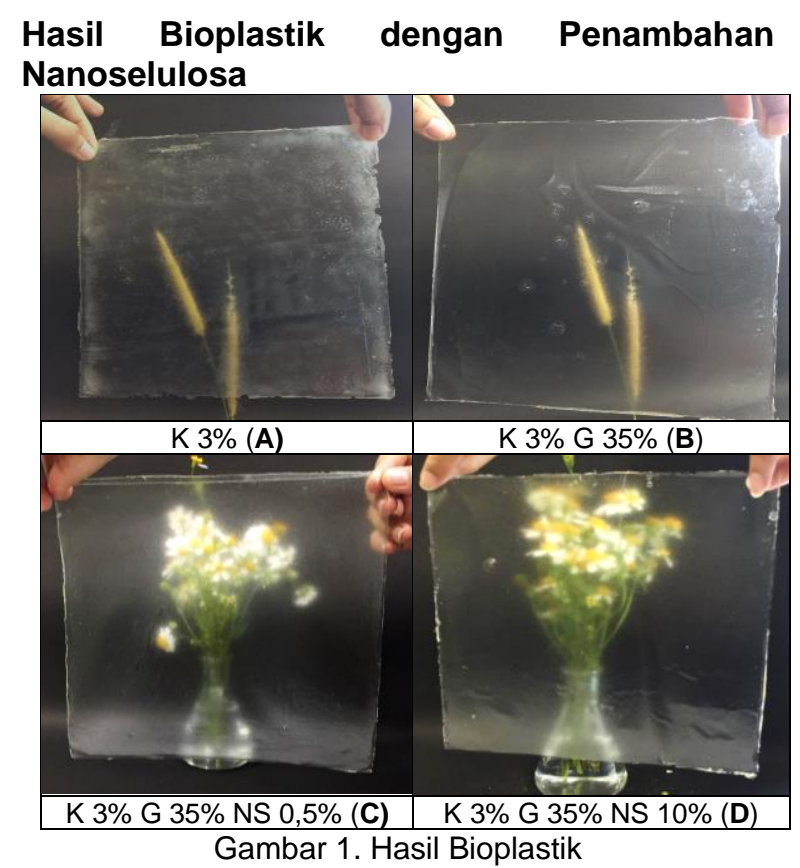

Pengaruh penambahan nanoselulosa menjadikan pembeda diantara bioplastik dengan penambahan karagenan dan gliserol yang ditunjukkan pada Gambar 3. Sifat fisik yaitu kecerahan warna dan adanya gelembung menjadi pembeda adanya pengaruh penambahan nanoselulosa. Pada perlakuan penambahan nanoselulosa pada bioplastik menjadikan warna lebih bening dengan kondisi lentur dan licin dibandingkan bioplastik Karagenan 3\% (Gambar 3.A) dan Karagenan 3\% Gliserol 35\% (Gambar 3.B) yang juga ditemui adanya gelembung yang biasanya muncul saat pencetakan dan penyimpanan di oven. Namun, penambahan nanoselulosa $0,5 \%$ sampai nanoselulosa $10 \%$ tidak memperlihatkan perbedaan yang nyata terhadap kecerahan warna.

\section{Ketebalan Rata-Rata}

Pengujian ketebalan berfungsi untuk mengetahui kualitas bioplastik dan menentukan ketahanan film terhadap sifat mekanik, laju perpindahan uap air, gas, dan senyawa volatil lainnya (Katili et al., 2013). Ketebalan bioplastik dengan rata-rata tertinggi ditunjukkan pada Tabel 2. Yaitu pada bioplastik dengan konsentrasi nanoselulosa $10 \%$ dengan nilai sebesar $0,15 \mathrm{~mm}$ dan nilai gramatur sebesar $0,008 \mathrm{~g} / \mathrm{m}^{2}$. Hasil analisis sidik ragam atau Analysis of Variance (ANOVA) pada uji ketebalan dengan taraf $5 \%$ menunjukan bahwa konsentrasi nanoselulosa tidak berpengaruh nyata terhadap ketebalan bioplastik. Penambahan konsentrasi nanoselulosa mempunyai nilai signifikasi (Sig.) = $0,460(>0,05)$ dan nilai $F$ hitung $<F$ Tabel $5 \%$ $(0,980<3,111)$ sehingga $H_{0}$ diterima dan disimpulkan bahwa tidak dapat dilakukan uji lanjut.
Nilai ketebalan bioplastik komersial sesuai Japanesse Industrial Standart (JIS) sebesar s $0,25 \mathrm{~mm}$ (Santoso et al., 2016). Sebagai pembanding yaitu bioplastik k-karagenan $1 \%$ dan PEG 300 dengan konsentrasi 30\% memiliki ketebalan sebesar 4,267 mm (Balqis et al., 2017). Plastik komersial memiliki ketebalan sebesar 0,2 mm (N. Lazuardi et al., 2013). Sehingga dapat disimpulkan bioplastik pada penelitian ini memiliki ketebalan yang telah sesuai dengan JIS 2-1707 serta hampir sama dengan plastik komersial. Menurut (Fajriati et al., 2017), umumnya peningkatan ketebalan terjadi karena adanya serat nanoselulosa yang membentuk lapisan disela-sela matriks bioplastik karagenan \& gliserol yang menyebabkan jarak antar polimer semakin dekat dan mengakibatkan total padatan di dalam komposit plastik meningkat karna polimer-polimer yang menyusun komposit bioplastik semakin banyak. Semakin tebal maka permeabilitas gas semakin kecil dan mampu menghambat laju air (Ulfimarjan, 2016).

\section{Water Solubility}

Uji Kelarutan berfungsi untuk mengetahui tingkat atau kemampuan kelarutan bioplastik dalam air. Water solubility terbaik (rata-rata terendah) ditunjukan pada Tabel 2. dengan konsentrasi nanoselulosa $1 \%$ dan nilai sebesar $61,28 \%$. Hasil analisis sidik ragam atau ANOVA pada uji water solubility dengan taraf $5 \%$ menunjukan bahwa konsentrasi nanoselulosa tidak berpengaruh nyata terhadap water solubility bioplastik. Penambahan konsentrasi nanoselulosa mempunyai nilai signifikasi (Sig.) = $0,405(>0,05)$ dan nilai $F$ hitung < F Tabel 5\% $(1,111<3,111)$ sehingga $\mathrm{H}_{0}$ diterima dan disimpulkan bahwa tidak dapat dilakukan uji lanjut.

Nilai kelarutan bioplastik dapat diukur dengan membandingkannya pada ketahanan air bioplastik dengan perhitungan yaitu ketahanan air $(\%)=100 \%$ - water solubility (\%). Nilai ketahanan air komersial sesuai SNI sebesar 99\% (Rahmadani, 2020). Sebagai pembanding yaitu bioplastik k-karagenan 1\% dan PEG 300 
Tabel 2. Hasil Karakterisasi Bioplastik Dengan Penambahan Nanoselilosa

\begin{tabular}{|c|c|c|c|c|c|c|c|c|c|}
\hline \multirow{2}{*}{ Sampel } & \multicolumn{7}{|c|}{ Karakterisasi Bioplastik } \\
\cline { 2 - 9 } & $\begin{array}{c}\text { Ketebal } \\
\text { an } \\
\text { Rerata } \\
(\mathrm{mm})\end{array}$ & $\begin{array}{c}\text { Water } \\
\text { Soubilit } \\
\begin{array}{c}\text { (\%) } \\
(\%)\end{array}\end{array}$ & $\begin{array}{c}\text { Kada } \\
\text { r Air } \\
(\%)\end{array}$ & $\begin{array}{c}\text { WVTR } \\
\left(\mathrm{gm}^{-2} \mathrm{~s}^{-1}\right)\end{array}$ & $\begin{array}{c}\text { Kuat } \\
\text { Tarik } \\
(\text { Mpa } \\
\text { ) }\end{array}$ & $\begin{array}{c}\text { Persen } \\
\text { Peman } \\
- \\
\text { jangan } \\
(\%)\end{array}$ & $\begin{array}{c}\text { Modulus } \\
\text { Young } \\
(\mathrm{Gpa})\end{array}$ & $\begin{array}{c}\text { Laju } \\
\text { Biodegradas } \\
\text { i } \\
\text { (gr/hari) }\end{array}$ \\
\hline K 3 & 0,050 & 28,145 & $\begin{array}{c}18,44 \\
0\end{array}$ & 0,26329 & 1,253 & 12,223 & 0,0132 & - \\
\hline K 3 G 35 & 0,103 & 42,300 & $\begin{array}{c}16,45 \\
0\end{array}$ & 0,21063 & 2,825 & 28,481 & 0,0173 & - \\
\hline $\begin{array}{c}\text { K 3 G 35 } \\
\text { NS 0,5 }\end{array}$ & 0,141 & 70,922 & $\begin{array}{c}19,65 \\
6\end{array}$ & 0,47393 & 8,161 & 51,372 & 0,0372 & 0,081 \\
\hline $\begin{array}{c}\text { K 3 G 35 } \\
\text { NS 1 }\end{array}$ & 0,151 & 61,285 & $\begin{array}{c}21,89 \\
5\end{array}$ & 0,52661 & 7,304 & 43,881 & 0,0335 & $-1,001$ \\
\hline $\begin{array}{c}\text { K 3 G 35 } \\
\text { NS 2,5 }\end{array}$ & 0,152 & 64,060 & $\begin{array}{c}20,42 \\
7\end{array}$ & 0,47393 & 9,132 & 52,234 & 0,0359 & $-1,369$ \\
\hline $\begin{array}{c}\text { K 3 G 35 } \\
\text { NS 5 }\end{array}$ & 0,145 & 69,926 & $\begin{array}{c}23,77 \\
1\end{array}$ & 0,47393 & 8,501 & 51,839 & 0,0370 & $-1,421$ \\
\hline $\begin{array}{c}\text { K 3 G 35 } \\
\text { NS 7,5 }\end{array}$ & 0,150 & 66,584 & $\begin{array}{c}28,11 \\
5\end{array}$ & 0,47393 & 7,091 & 64,625 & 0,0230 & $-2,100$ \\
\hline $\begin{array}{c}\text { K 3 G 35 } \\
\text { NS 10 }\end{array}$ & 0,153 & 64,468 & $\begin{array}{c}30,51 \\
5\end{array}$ & 0,42127 & 7,358 & 45,616 & 0,0365 & $-2,173$ \\
\hline $\begin{array}{c}\text { Bioplastik } \\
\text { Komersial }\end{array}$ & $0,2 \mathrm{a}$ & $30^{\mathrm{a}}$ & $\begin{array}{c}7,933 \\
\mathrm{~b}\end{array}$ & $\begin{array}{c}0,00166 \\
\mathrm{c}\end{array}$ & 50,36 & $4,36^{\mathrm{d}}$ & $0,003^{\mathrm{d}}$ & $0,42^{\mathrm{a}}$ \\
\hline
\end{tabular}

dengan konsentrasi $30 \%$ memiliki nilai water solubility sebesar $81,01 \%$ (Balqis et al., 2017). Kemudian, menurut (N. Lazuardi et al., 2013) plastik komersial memiliki nilai water solubility sebesar 30\%, sehingga menunjukan bahwa plastik pada penelitian ini masih sangat jauh dari bioplastik yang ada dipasaran. Semakin besar konsentrasi nanoselulosa maka serat dapat lebih banyak menahan air, karena bentuknya yang berlapis dan susunan yang lebih rapat. Saat menyerap air, bioplastik akan menjadi gel yang menggembung dan apabila telah mencapai titik maksimum maka akan terpecah. Semakin tinggi konsentrasi nanoselulosa maka titik maksimum bioplastik untuk mampu menahan air semakin besar, dan memiliki konsentrasi, kekentalan, dan sifat penghalang yang tinggi (Widyaningsih, 2012). Jika dibandingkan dengan nilai kelarutan pada bioplastik karagenan 3\% dan karagenan 3\% gliserol 35\%, penambahan nanoselulosa memiliki nilai yang lebih besar, karena sifat ketiga bahan yang hidrofilik dan banyaknya ikatan hidrogen memberikan peluang untuk berikatan dengan air (Bourbon et al., 2011).

\section{Kadar Air}

Pengujian kadar air dilakukan untuk mengetahui berat bahan kering, menganalisis kandungan zat sutu bahan, dan kerusakan bahan. Kadar air terbaik (rata-rata terendah) ditunjukan pada Tabel 2. dengan konsentrasi nanoselulosa $0,5 \%$ dengan nilai sebesar $19,66 \%$.
Hasil analisis sidik ragam atau ANOVA pada uji kadar air dengan taraf $5 \%$ menunjukan bahwa konsentrasi nanoselulosa berpengaruh nyata terhadap kadar air bioplastik. Penambahan konsentrasi nanoselulosa mempunyai nilai signifikasi (Sig.) $=0,040(<0,05)$ dan nilai $F$ hitung $<\mathrm{F}$ Tabel $5 \%(3,345<3,111)$ sehingga $\mathrm{H}_{1}$ diterima dan disimpulkan bahwa konsentrasi nanoselulosa memberikan pengaruh yang nyata pada uji kadar air. Pada uji lanjut DMRT konsentrasi nanoselulosa terbaik terdapat pada nanoselulosa $0,5 \%$ karena memiliki perbedaan yang signifikan pada subset.

Menurut (Darmajana et al., 2015) plastik kemasan buah memiliki kadar air edible film sebesar 19,35\% dengan kadar air buah saat pengemasan sekitar $85 \%$. Sebagai pembanding yaitu bioplastik k-karagenan 1\% dan PEG 300 dengan konsentrasi $30 \%$ memiliki kadar air sebesar 21,69\% (Balqis et al., 2017). Menurut (Oluwisana et al., 2019) bioplastik konvensional memiliki kadar air sebesar 7,933\%. Sehingga dapat disimpulkan bahwa bioplastik pada penelitian ini telah sesuai dengan referensi yang ada dan jika dibandingkan dengan bioplastik karagenan dan PEG 300 memiliki kadar air yang lebih baik, namun masih lebih tinggi jika dibandingkan dengan LDPE.

Semakin bertambahnya konsentrasi nanoselulosa pada bioplastik menyebabkan tingginya kadar air. Hal ini disebabkan sifatnya yang hidrofilik dan penambahan air dari kandungan bahan baku bioplastik sangat tinggi dibanding total bahan (Anandito et al., 2012). Proses gelatinisasi juga akan merusak ikatan 
hidrogen intermolekuler dimana ikatan hidrogen ini berfungsi untuk mempertahankan struktur integritas bahan, sehingga kadar air yang terukur menjadi rendah (Rangel et al., 2013). Nanoselulosa juga akan meningkatkan laju penyerapan air pada proses bleaching karena terdapat ruang kosong akibat peluruhan hemiselulosa dan lignin yang memicu penyerapan kelembapan pada serat (Mandal \& Debrata, 2011).

\section{Water Vapor Transmission Rate (WVTR)}

Uji WVTR menunjukan jumlah transmisi uap \& air yang dapat terlewat melalui lapisan film bioplastik dan berfungsi untuk mengetahui permeability bahan bioplastik. WVTR terbaik (rata-rata terendah) ditunjukan pada Tabel 2. dengan konsentrasi nanoselulosa $10 \%$ dengan nilai sebesar 0,42127 $\mathrm{gs}^{-1} \mathrm{~m}^{-2}$. Hasil analisis sidik ragam atau ANOVA pada uji WVTR dengan taraf $5 \%$ menunjukan bahwa konsentrasi nanoselulosa tidak berpengaruh nyata terhadap nilai WVTR bioplastik. Penambahan konsentrasi nanoselulosa mempunyai nilai signifikasi (Sig.) = $0,366(>0,05)$ dan nilai $F$ hitung < F Tabel 5\% $(1,200<3,111)$ sehingga $\mathrm{H}_{0}$ diterima sehingga tidak dapat dilakukan uji lanjut. Tidak berpengaruhnya hasil uji dan meningkatnya nilai WVTR dibandingkan bioplastik karagenan 3\% Gliserol 35\% disebabkan oleh massa yang berkurang pada saat pengujian sangat kecil sehingga ketika dibuat grafik regresi memiliki nilai slope yang sama dan ketebalan yang kurang presisi pada setiap ulangan.

Nilai maksimal WVTR menurut JIS 2-1707 sebesar 0,00008 g/m²/s (Santoso et al., 2016). Sebagai pembanding yaitu bioplastik kkaragenan 1,5\% dan PEG 400 dengan konsentrasi 4\% memiliki nilai WVTR sebesar $0,001342 \mathrm{~g} / \mathrm{m}^{2} / \mathrm{s}$ (Fransiska et al., 2018). Bioplastik komersial yang memiliki nilai dalam kisaran 0,00166 g/m²/s (Apriani \& Sedyani, 2015). Maka disimpulkan plastik pada penelitian ini masik memiliki transmisi uap air yang jauh dibawah bioplastik karagenan dengan penambahan PEG 400, standar bioplastik dan bioplastik komersial.

Hasil nilai WVTR dengan penambahan nanoselulosa memiliki nilai yang lebih besar karena menurut (Rahim, 2017) penggunaan konsentrasi nanoselulosa yang tinggi menyebabkan bertambah serat yang dapat meningkatkan jumlah ikatan antar molekul sehingga menurunkan permeabilitas uap air. Kondisi tersebut juga dapat disebabkan oleh sifat ketiga bahan yang tergolong hidrofilik sehingga menurunkan tegangan antar molekul pada matriks edible film dan menyebabkan ruang antar molekul semakin besar sehingga uap air bisa menembus edible film. Selain itu, sifat hidrofilisitas juga meningkatkan laju transmisi uap air film (Plackett et al., 2010).

\section{Universal Attenuated Total Reflectance Fourier Transform Infra-Red (UATR-FTIR) Bioplastik Karagenan-Gliserol-Nanoselulosa}

Analisis UATR-FTIR didapatkan reaksi berupa keberadaan gugus-gugus fungsi molekul yang terdapat pada campuran ketiga sampel. Data spektroskopi yang digunakan untuk identifikasi mengacu pada data spektrum karagenan, gliserol, dan nanoselulosa standar. Pada nanoselulosa terjadi reaksi Pengujian spektrum UATR-FTIR pada hasil optimal proses ektraksi karagenan memperlihatkan struktur kimia karagenen jenis kappa karagenan, dengan menunjukkan adanya ikatan $\mathrm{S}=\mathrm{O}$ gugus ester sulfat pada spektrum 1255,99-1303,56 cm-1, ikatan glikosidik pada spektrum 1025,09 $\mathrm{cm}^{-1}$, adanya ikatan C-O gugus 3,6 anhidro-galaktosa pada spektrum 1151,16-916,78 $\mathrm{cm}^{-1}$, dan adanya ikatan $\mathrm{CO}-\mathrm{SO}_{3}$ pada gugus fungsi galaktosa 4-sulfat yang mengidentifikasi jenis kkaragenan pada spektrum 843,25-892,47 $\mathrm{cm}^{-1}$. Spektrum menunjukkan bahwa karagenan hasil isolasi telah memenuhi spesifikasi dengan karaginan komersial karena gugus-gugus fungsi yang terdapat pada spektrum karagenan sampel yang dihasilkan identik dengan spektrum standar karagenan (Fardyanti \& Julianur, 2015).

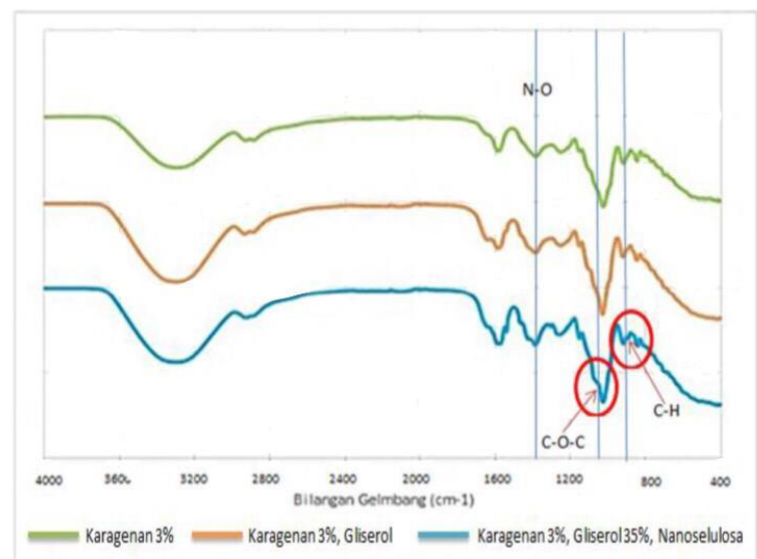

Gambar 2. UATR-FTIR Bioplastik Karagenan-GliserolNanoselulosa

Penambahan gliserol mengakibatkan meningkatnya bilangan gelombang gugus fungsi $-\mathrm{OH}$ karboksil menjadi $3305,9 \mathrm{~cm}^{-1}$, reaksi ini terjadi karena gliserol memiliki strukur kimia berupa ikatan hidrogen yang kuat dan membentuk ikatan hidrogen intramolekuler termasuk dengan molekul air sehingga menghasilkan sifat plastik yang hidrofilik (Utami et al., 2014). Puncak serapan yang khas dari selulosa yaitu gugus $\mathrm{OH}$ pada daerah 3294,92 $\mathrm{cm}^{-1}$ dari ikatan glikosida dan gugus $\mathrm{C}-\mathrm{O}-\mathrm{C}$ pada 
daerah $1024 \mathrm{~cm}^{-1}$ dari cincin selulosa. Daerah $769,91 \mathrm{~cm}^{-1}$ menunjukkan puncak serapan karena adanya getaran $\mathrm{C}-\mathrm{H}$ dari rantai $\beta$ glikosidik yang merupakan penghubung antar unit glukosa pada selulosa. Hasil dari mekanisme reaksi dari ketiga bahan ditemukan bahwa puncak-puncak pada penambahan selulosa lebih tajam dibandingkan pada sampel tanpa penambahan selulosa, dikarenakan adanya pengaruh gugus-gugus pada spectra bioplastik, Hasil UATR-FTIR pada Gambar 4 menunjukkan tidak adanya reaksi kemunculan gugus fungsi yang baru diluar dari gugus bawaan yang berasal dari bahan, dengan kata lain secara kimia tidak terjadi perubahan pada bioplastik. Terlihat bahwa bahan bioplastik yang dihasilkan sudah tercampur dengan baik secara fisika, serta menggambarkan bahan bioplastik tersebut masih memiliki sifat hidrofilik seperti sifat penyusunnya.

\section{Kuat Tarik}

Pengujian kuat tarik berfungsi untuk mengetahui tegangan maksimum bahan bioplastik. Kuat tarik terbaik (rata-rata tertinggi) ditunjukkan pada Tabel 2. dengan konsentrasi nanoselulosa 2,5\% dan nilai sebesar 9,132 Mpa. Hasil analisis sidik ragam atau ANOVA pada uji kuat tarik dengan taraf $5 \%$ menunjukan bahwa konsentrasi nanoselulosa berpengaruh nyata terhadap kuat tarik bioplastik. Penambahan konsentrasi nanoselulosa mempunyai nilai signifikasi (Sig.) $=0,037(<0,05)$ dan nilai $F$ hitung $<\mathrm{F}$ Tabel $5 \%(4,180>3,111)$ sehingga $\mathrm{H}_{1}$ diterima dan disimpulkan bahwa konsentrasi nanoselulosa memberikan pengaruh yang nyata pada uji kuat tarik. Pada uji lanjut Duncan's Multiple Range Test (DMRT) disimpulkan bahwa konsentrasi nanoselulosa terbaik terdapat pada nanoselulosa 2,5\% karena memiliki perbedaan yang signifikan pada subset.

Menurut penelitian yang dilakukan oleh (Budiman et al., 2018), untuk mengukur kuat tarik bioplastik digunakan minimal JIS-2-1707dengan nilai kuat tarik minimal sebesar $3.92266 \mathrm{Mpa}$. Sebagai pembanding yaitu bioplastik kkaragenan 1,5\% dan PEG 400 dengan konsentrasi $4 \%$ memiliki nilai kuat tarik sebesar 0,86 Mpa (Fransiska et al., 2018). (Widyaningrum et al., 2020) menyebutkan bioplastik komersial memiliki nilai kuat tarik sebesar 50,36 Mpa. Sehingga dapat disimpulkan bahwa bioplastik telah sesuai dengan standar yang ada dan memiliki nilai yang lebih baik dibandingkan bioplastik karagenan dengan campuran PEG 400, namun apabila dibandingkan bioplastik komersial masih memiliki nilai yang jauh.

Nanoselulosa pada konsentrasi optimum mampu meningkatkan kekuatan mekanik bioplastic (Darni et al., 2009). Peningkatan kekuatan tarik akibat peningkatan interaksi gaya tarik-menarik antar molekul penyusun lapisan tipis, membentuk ikatan hidrogen antar dan intramolekul membentuk lapisan tipis yang terdiri atas serat-serat yang saling menguatkan (Septiosari et al., 2014). Nanoselulosa menunjang nilai kuat tarik karena sifat tanpa cacat (dislocation, flaw, kink, defect) dan keseragaman struktur material berukuran nano (Fitriasari et al., 2019).

\section{Persen Pemanjangan (\%-Elongation)}

Persen pemanjangan menunjukkan perubahan panjang maksimum pada saat terjadi peregangan hingga sampel film terputus. Persen pemanjangan terbaik (rata-rata tertinggi) ditunjukkan pada Tabel 2. dengan konsentrasi nanoselulosa $7,5 \%$ dan nilai sebesar $64,625 \%$. Hasil analisis sidik ragam atau ANOVA pada uji persen pemanjangan dengan taraf $5 \%$ menunjukan bahwa konsentrasi nanoselulosa berpengaruh nyata terhadap persen pemanjangan bioplastik. Penambahan konsentrasi nanoselulosa mempunyai nilai signifikasi (Sig.) $=0,013(<0,05)$ dan nilai F hitung $<\mathrm{F}$ Tabel $5 \%(3,275>3,111)$ sehingga $\mathrm{H}_{1}$. Pada uji lanjut DMRT disimpulkan bahwa konsentrasi nanoselulosa terbaik terdapat pada nanoselulosa $7,5 \%$ karena memiliki perbedaan yang signifikan pada subset.

Menurut penelitian yang dilakukan oleh (Budiman et al., 2018), nilai \%-elongation sesuai JIS-2-1707 sebesar $>50 \%$. Sebagai pembanding yaitu bioplastik k-karagenan 1,5\% dan PEG 400 dengan konsentrasi $4 \%$ memiliki nilai \%pemanjangan sebesar 25,40 \% (Fransiska et al., 2018). (Widyaningrum et al., 2020) bioplastik komerisal memiliki nilai persen pemanjangan sebesar $4,363 \%$. Sehingga dapat disimpulkan bahwa bioplastik telah sesuai dengan standar yang ada dan memiliki nilai yang lebih baik dibandingkan bioplastik karagenan dengan campuran PEG 400, dan bioplastik komersial.

Interaksi interfibril yang kuat antara nanoselulosa menyebabkan transparansi yang tinggi, kekuatan tarik yang kuat, dan modulus yang tinggi tetapi perpanjangan film berbasis nanoselulosa yang rendah saat putus (Sunardi et al., 2020). Nanoselulosa mampu meningkatkan mobilitas polimer dan afinitas tinggi sehingga menyebabkan meningkatnya kemampuan ulur molekul (Syariffudin \& Yunianta, 2015). Peningkatan konsentrasi nanoselulosa juga menyebabkan penurunan rasio gliserol sebagai plasticizer, sehingga mengakibatkan penurunan elongasi film apabila terkena gaya, yang kemudian menyebabkan film mudah patah (Anandito et al., 2012).

\section{Modulus Young}

Modulus Young dilakukan untuk mengetahui sifat mekanik dari material bioplastik berupa kekuatan dan kekakuan. Modulus young terbaik (rata-rata tertinggi) ditunjukkan pada Tabel 2. dengan konsentrasi nanoselulosa $0,5 \%$ 
dan nilai sebesar 0,037222 Gpa. Hasil analisis sidik ragam atau ANOVA menunjukan bahwa konsentrasi nanoselulosa berpengaruh nyata terhadap nilai modulus young bioplastik. Penambahan konsentrasi nanoselulosa mempunyai nilai signifikasi (Sig.) $=0,023(<0,05)$ dan nilai $F$ hitung $<F$ Tabel $5 \%(3,603>3,111)$ sehingga $\mathrm{H}_{1}$ diterima dan disimpulkan bahwa konsentrasi nanoselulosa memberikan pengaruh yang nyata pada uji modulus young. Pada uji lanjut DMRT disimpulkan bahwa konsentrasi nanoselulosa terbaik terdapat pada nanoselulosa $0,5 \%$ karena memiliki perbedaan yang signifikan pada subset.

Menurut penelitian yang dilakukan oleh (Budiman et al., 2018), nilai modulus young sesuai JIS-2-1707 sebesar 0,00035 Gpa. Sebagai pembanding yaitu bioplastik kkaragenan 1,5\% dan PEG 400 dengan konsentrasi 4\% memiliki nilai \%-pemanjangan sebesar 0,003379 Gpa (Fransiska et al., 2018). (N. Lazuardi et al., 2013) menyebutkan bahwa bioplastik komersial memiliki nilai modulus young sebesar 0,003 Gpa. Sehingga dapat disimpulkan bahwa bioplastik telah sesuai dengan standar yang ada dan memiliki nilai yang lebih baik dibandingkan bioplastik karagenan dengan campuran PEG 400, namun apabila dibandingkan bioplastik komersial masih memiliki nilai yang jauh.

(Nisak, 2018) menyebutkan penambahan nanoselulosa dengan konsentrasi optimum mampu meningkatkan kekakuan film polimer dengan cara menguatkan ikatan hidrogen antara molekul polimer yang berdekatan sehingga kekuatan tarik-menarik intermolekul rantai polimer menjadi menguat (Manalu et al., 2013). (Bahmid, 2014) juga menyebutkan bahwa semakin kecil ukuran serat nanoselulosa yang digunakan maka semakin tinggi nilai modulus young karena mobilitas rantai polimer semakin meningkat. Tingkat kerapatan susunan serat nano juga menyebabkan kerapatan lebih besar sehingga meningkatnya nilai kekakuan (Gunawan et al., 2016).

\section{Biodegradasi}

Uji biodegradabelitas dilakukan dengan tujuan untuk mengetahui laju degradasi sampel sehingga dapat diramalkan berapa lama sampel tersebut akan terurai oleh mikroorganisme. Laju degradasi terbaik (rata-rata tertinggi) ditunjukkan pada Tabel 2. dengan konsentrasi nanoselulosa $0,5 \%$ dan nilai sebesar $0,081 \mathrm{gr} /$ hari dengan \%kehilangan massa sebesar $8 \%$ pada waktu 25 hari. Hasil analisis sidik ragam atau ANOVA pada uji laju degradasi dengan taraf $5 \%$ menunjukan bahwa konsentrasi nanoselulosa berpengaruh nyata terhadap nilai laju degradasi bioplastik. Penambahan konsentrasi nanoselulosa mempunyai nilai signifikasi (Sig.) $=0,001(<0,05)$ dan nilai $F$ hitung < F Tabel 5\% $(8,982>3,111)$ sehingga $\mathrm{H}_{1}$ diterima. Pada uji lanjut DMRT disimpulkan bahwa konsentrasi nanoselulosa terbaik terdapat pada nanoselulosa $0,5 \%$ karena memiliki perbedaan yang signifikan pada subset.

Menurut penelitian yang dilakukan oleh (Sumartono, 2015) untuk mengukur biodegradasi bioplastik digunakan standar bioplastik internasional ASTM G21-2015 yang menyebutkan bahwa lama degradasi pada bioplastik membutuhkan waktu 60 hari untuk terdegradasi. Lalu, berdasarkan penelitian yang dilakukan (N. Lazuardi et al., 2013) pada bioplastik komersial dengan hasil yaitu mampu terdegradsi sebesar 18,9\% setelah 45 hari Sehingga dapat disimpulkan bahwa bioplastik pada penelitian ini memiliki laju degradasi yang sesuai dengan standar, lebih baik dibandingkan bioplastik komersial, dan dapat dikatakan plastik biodegradabel.

Sifat karagenan, gliserol, dan nanoselulosa yang cenderung bersifat hidrofilik mempercepat laju degradasi dan penyusutan massa (Gontard et al., 1993). Nanoselulosa mudah terdegradasi karena memiliki kemampuan daya serap air yang tinggi, dan sangat mempengaruhi kekuatan rantai dan tingginya gaya antar rantai dari ikatan hidrogen antar gugus hidroksil pada rantai yang menyebabkan mudah berinteraksi dengan adanya aktivitas beberapa mikroba yang terdapat pada EM4 (Lazuardi \& Cahyaningrum, 2013). Penggunaan EM4 juga dapat mendegradasi bioplastik dengan cepat karena putusnya rantai polimer menjadi monomer-monomer yang terurai dan mengakibatkan berkurangnya massa (Tyasning \& Masyukri, 2013).

\section{KESIMPULAN}

Bioplastik terbaik dapat dihasilkan dengan konsentrasi karagenan sebesar 3\% dan Gliserol $35 \%$, melalui metode blending dengan penambahan konsentrasi nanoselulosa $0,5 \%$; $1 \% ; 2,5 \% ; 5 \% ; 7,5 \% ; 10 \%$. Nanoselulosa dapat diperoleh menggunakan ultrafine grinder pada gap -15 dengan 5 kali sirkulasi pada setiap gap yang memiliki diameter dibawah $100 \mathrm{~nm}$. Hasil analisis sidik ragam (ANOVA) menunjukkan bahwa pemberian perlakuan konsentrasi nanoselulosa tidak memiliki pengaruh terhadap karakteristik sifat bioplastik seperti ketebalan, water solubility, dan water vapor transmission rate (WVTR). Namun, berpengaruh nyata terhadap karakteristik sifat bioplastik seperti kadar air (Nanoselulosa 0,5\% ; 19,656\%), kuat tarik (Nanoselulosa 2,5\% ; 93,120 $\mathrm{KgF} / \mathrm{cm}^{2}$ atau 9,132 Mpa), \%-perpanjangan (Nanoselulosa $7,5 \% ; 64,625 \%$ ), modulus young (Nanoselulosa 0,5\% ; 37,222 Mpa atau 0,037222 Gpa), dan biodegradasi (Nanoselulosa 0,5\% ; 8\% selama 25 hari). Dan dari hasil karakteristik tersebut telah 
sesuai dengan standar yang ada, kecuali water solubility dan WVTR. Disimpulkan bahwa pemberian nanoselulosa hanya dapat memperbaiki sifat mekanik pada bioplastik karagenan dan mampu menurunkan nilai kadar

\section{DAFTAR PUSTAKA}

Anandito, R Baskara Katri, Edhi Nurhartadi, and Akhmad Bukhori. 2012. "Pengaruh Gliserol Terhadap Karakteristik Edible Film Berbahan Dasar Tepung Jali (Coix Lacryma-Jobi L.)." Teknologi Hasil Pertanian 5 (2): 17-23.

Andrieti, Ristika. 2018. "Kemasan Pangan." Kementrian Perindustrian Balai Besar Kimia Dan Kemasan, 2018.

Azeredo, H.M.C, Rosa, M.F., Mattoso, L.H.C. 2017. "Nanocellulose in Bio-Based Food Packaging Applications." Industrial Crops and Products, no. 97: 664-71.

Bahmid, N.A., Khaswar, S., Akhiruddin, M. 2014. "Pengaruh Ukuran Dan Serat Selulosa Asetat Dan Penambahan Dietilen Glikol (DEG) Terhadap Sifat Fisik Dan Mekanik Bioplastik." Jurnal Teknologi Industri Pertanian 24 (3): 226-34.

Balqis, A.M.; Nor Khaizura, M.A.R.; Russly, A.R.; Nur Hanani, Z.A. 2017. "Effects of Plasticizers on the Physicochemical Properties of Kappa-Carrageenan Films Extracted from Eucheuma Cottonii." International Journal of Biological Macromoleculesl. s0141813016330665doi:10.1016/j.ijbiomac.2017.05.105.

Basriman, Iman., Harso, D., dan Mulyono, N. 2019. "Mutu Mikrobiologis Udang Selama Penyimpanan Dalam Kemasan Plastik Biodegradable Dengan Matriks Damar Daging Dan Pati Tapioka." Jurnal Teknologi Pangan Kesehatan 1 (1): 49-57.

Bourbon AI, Pinheiro AC, Cerqueira MA, Rocha CMR, Avides MC, Quintas MAC, Vicente AA. 2011. "Physico-Chemical Characterization Of Kitosan-Based Edible Films Incorporating Bioactive Compounds Of Different Molecular Weight." Journal of Food Engineering 106 (2): 111-18.

Budiman, Johan., Nopianti, Rodiana., dan Lestari, S. 2018. "No TitleKarakteristik Bioplastik Dari Pati Buah Lindur." FishtecH - Jurnal Teknologi Hasil Perikanan 28 (4): 273-79.

Carbone, M., Donia, D.T., Sabbatella, G., Antiochia, R. 2015. "Silver Nanoparticles in Polymeric Matrices for Fresh Food Packaging." Journal of King Saud University-Science 28 (4): 273-79.

Darmajana, D.A., Afifah, N., Sholichah, E. dan Indriyani, N. 2015. "Laporan Kegiatan Aplikasi Pengemas Edible Untuk BuahBuahan Tropis." Pusat Pengembangan air. Hal ini sesuai dengan sifat nanoselulosa yaitu mampu meningkatkan sifat mekanik seperti kekuatan, kekakuan, ketangguhan, dan perbaikkan sifat barrier.

Teknologi Tepat Guna, Lembaga IImu Pengetahuan Indonesia.

Darni, Y., Sitorus, T.M., Hanif, M. 2014. "Pengaruh Penambahan Selulosa Dari Rumput Laut Eucheuma Spinosum Pada Sintesa Bioplastik Berbasis Sorgum." Jurnal Rekayasa Kimia Dan Lingkungan 10 (2): 55-56.

Fajriati, I., Sedyadi, E., \& Sudarlin. 2017. "Sintesis Komposit Film Kitosan- TiO2 Menggunakan Sorbitol Sebagai Plasticizer." Jurnal Penelitian Kimia 13 (1): 77-87.

Fatriasari, Widya., Masruchin, Nananf., dan Hermiati, Euis. 2019. Selulosa Karakteristik Dan Pemanfaatannya. Jakarta: LIPI Press.

Fransiska, D., Giyatmi, Irianto, H.E., Darmawan, M., Melanie, S. 2018. "Karakteristik Film KKaraginan Dengan Penambahan Plasticizer Polietilen Glikol." JPB Kelautan Dan Perikanan 13 (1): 62-67.

Gunawan, Y., Aksar, P., Irfan, L.O. 2016. "Analisa Pengaruh Ukuran Diameter Serat Tangkai Sagu Terhadap Sifat Mekanik Pada Material Komposit." Jurnal IImiah Mahasiswa Teknik Mesin 2 (2): 62-67.

Gutari, Sesmi. 2019. "Peran Zno Dan Tio 2 Pada Bioplastik Antimikroba Berbasis PlaKitosan." Institut Pertanian Bogor.

Hamid, H.A., Saupy, N.A.Z.M., Zain, N.M., Mudalip, S.K.A., Shaarani, S.M., Azman, N.A.M. 2018. "Development and Characterization of Semi-Refined Carragenan (SRC) Films from Eucheuma Cottoni Incorporated with Glycerol and $\alpha$ Tocopherol for Active Food Packaging Application." IOP Conf Series: Materials Science and Engineering, no. 458: 012022.

Harumarani, S., Ma'ruf, W.F., Romadhon. 2016. "Pengaruh Perbedaan Konsentrasi Gliserol Pada Karakterisasi Edible Film Komposit Semirefined Karagenan Eucheuma Cottoni Dan Besswax." Jurnal Pengolahan Dan Bioteknologi Hasil Perikanan 5 (1): 101-5.

Iriani, Evi Savitri, Kendri Wahyuningsih, Titi Candra Sunarti, and Asep Wawan Permana. 2015. "Sintesis Nanoselulosa Dari Serat Nanas Dan Aplikasinya Sebagainanofillerpada Film Berbasis Polivinil Alkohol." Jurnal Penelitian Pascapanen Pertanian 12 (1): 11. https://doi.org/10.21082/jpasca.v12n1.2015 .11-19.

Jonoobi, M., Oladi, R., Davaoudpour, Y. 2015. "Different Preparation Methods and Properties of Nanostructured Cellulose from Various Natural Resources and Residues: 
A Review." Cellulose 22: 935-69.

Kartini, A., dan Pandebesie, Elina. 2016. "Produksi Bioetanol Dari Batang Sorghum Bicolor (L.) Moench Dengan Saccharomyces Cerevisiae Dan Konsorsium S. Cerevisiae - Pichia Stipites." Jurnal Purifikasi 16 (2): 119-29.

Katili, S., Harsunu B T, \& Irawan S. 2013. "Pengaruh Konsentrasi Plasticizer Gliserol Dan Komposisi Khitosan Dalam Zat Pelarut Terhadap Sifat Fisik Edible Film Dari Khitosan." Jurnal Teknologi 6 (1): 29-38.

Khoirunnisa, A.R., Joni, I.M., Panatarani, C., Rochima, E., Praseptiangga, D. 2018. "UVScreening, Transparency and Water Barrier Properties of Semi Refined lota Carrageenan Packaging Film Incorporated with ZnO Nanoparticles." In AIP Conf Proceedings, 1927: 030041.

Lazuardi, Gilang., dan Cahyaningrum, Sari. 2013. "Pembuatan Dan Karakterisasi BioplastikBerbahan Dasar Kitosan Dan Pati Singkong Dengan Plasticizer Gliserol." UNESA Journal of Chemistr 2 (3): 42-51.

Manalu, Santika dan Yuli Darni. 2013. "Pengaruh Konsentrasi Plasticizer Terhadap Karakteristik Material Bioplastik Dan Uji Biodegradabilitasnya." Institut Teknologi Bandung.

Mandal, Arup., Chakrabarty, Debabrata. 2011. "Isolation of Nanocellulose from Waste Sugarcane Bagasse (SCB) and Its Characterization." Carbohydrate Polymers 86 (3): 1291-99.

Maryuni, A.E., Mangiwa, S., Dewi, W.K. 2018. "Karakterisasi Bioplastik Dari Karaginan Dari Rumput Laut Merah Asal Kabupaten Biak Yang Dibuat Dengan Metode Blending Menggunakan Pemlastis Sorbitol." Jurnal Kimia Avogadro 2 (1): 1-9.

Nisak, Aniqotun. 2018. "Optimasi Konsentrasi Nanokristalin SelulosaDari Ampas Tebu (Sugarcane Officanarium) Sebagai Bahan Alternatif Pembuatan Kapsul Bebas Gelatin." UIN Maulana Malik Ibrahim.

Oluwasina, Olugbenga O.; Olaleye, Feranmi K.; Olusegun, Sunday J.; Oluwasina, Olayinka O.; Mohallem, Nelcy D.S. 2019. "Influence of Oxidized Starch on Physicomechanical, Thermal Properties, and Atomic Force Micrographs of Cassava Starch Bioplastic Film." International Journal of Biological Macromolecules 135: 282-93.

Panjaitan, R., Irdoni., dan Bahruddin. 2017. "Pengaruh Kadar Dan Ukuran Selulosa Berbasis Batang Pisang Terhadap Sifat Dan Morfologi Bioplastik Berbahan Pati Umbi Talas." Jom FTEKNIK 4 (1): 1-7.

Plackett $\mathrm{D}$, Anturi $\mathrm{H}$, Hedenqvist M, Ankerfors M, Gallstedt M, Lindstrom T, Siro I. 2010. "Physical Properties And Morphology Of
Films Prepared From Microfibrillated Cellulose And Microfibrillated Cellulose In Combination With Amylopectin." J Appl Polym Sci 117: 3601-9.

Rahim, A., Syahraeni Kadir and Jusman. 2017. "The Influence Degree Of Substitution On The Physicochemical Properties Of Acetylated Arenga Starches." International Food Research Journal 24 (1): 102-7.

Rahmadani, Sry. 2020. "Pemanfaatan Pati Batang Ubi Kayu Dan Pati Ubi Kayu Untuk Bahan Baku Alternatif Pembuatan Plastik Biodegradable." Jurnal Teknologi Kimia Unimal 8 (1): 26-35.

Rangel-Marrón, M., Montalvo-Paquini C., Palou E, López-Malo A. 2013. "Optimization of the Moisture Content, Thickness, Water Solubility and Water Vapor Permeability of Sodium Alginate Edible Films." In . Recent Advances in Chemical Engineering, Biochemistry and Computational Chemistry.

Rifaldi, Anugrah., HS, Irdhoni., dan Bahruddin. 2017. "Sifat Dan Morfologi Bioplastik Berbasis Pati Sagu Dengan Penambahan Filler Clay Dan Plasticizer Gliserol." Jom FTEKNIK 4 (1).

Santoso, A.I. 2011. "Pengaruh Penggunaan Edible Coating Terhadap Susut Bobot, $\mathrm{PH}$, Dan Karakteristik Organoleptik Buah Potong Pada Penyajian Hidangan Dessert." Universitas Negeri Jakarta.

Saputri, Lestari dan Sukmawa, Romi. 2020. "Pengaruh Proses Blending Dan Ultrasonikasi Terhadap Struktur Morfologi Ekstrak Serat Limbah Batang Kelapa Sawit Untuk Bahan Baku Bioplastik (Selulosa Asetat)." Journal of Science and Technology 13 (1): 15-21.

Sedayu, B.B., Cran, M.J., Bigger, S.W. 2020. "Reinforcement of Refined and SemiRefined Carrageenan Film with Nanocellulose." Polymers 12: 1-2.

Septiosari, Arum., Latifah., dan Kusumastuti, Ella. 2014. "Pembuatan Dan Karakterisasi Bioplastik Limbah Biji Mangga Dengan Penambahan Selulosa Dan Gliserol." J. Chem. Sci 3 (2): 158-68.

Sumartono, N., Handayani, F., Desiriana, R., Novitasari, W., dan Hulfa, D. 2015. "Sintesis Dan Karakterisasi Bioplastik Berbasis Alang-Alang (Imperata Cylindrica(L.)) Dengan Penambahan Kitosan, Gliserol, Dan Asam Oleat." Universitas Negeri Yogyakarta.

Sunardi., Trianda, Nur., dan Irawati, Utami. 2020. "Pengaruh Nanoselulosa Dari Pelepah Nipah Sebagai Filler Terhadap Sifat Bioplastik Polivinil Alkohol." Justek: Jurnal Sains Dan Teknologi 3 (2): 69-76.

Tyasning, Diah. dan Masykuri, M. 2013. "Pengaruh Penambahan Kitosan Terhadap 
Biodegradasi Plastik Berbahan Dasar Polipropilen." Universitas Sebelas Maret.

Ulfimarjan. 2016. "Pengaruh Konsentrasi Kitosan Terhadap Karakteristik Bioplastik Pati Sagu." Universitas Andalas.

Utami, M.R., Latifah, \& N. Widiarti. 2014. "Sintesis PlastikBiodegradabledari Kulit Pisang Dengan Penambahan Kitosan Dan Plasticizer Gliserol.” Indonesian Journal Of Chemical Science 3 (2): 163-16.

Widyaningrum, Bernadeta Ayu, Wida Banar Kusumaningrum, Firda Aulya Syamani, Dwi Ajias Pramasari, Sukma Surya Kusuma, Fazhar Akbar, Rahyani Ermawati, and Agustina Arianita Cahyaningtyas. 2020. "Karakteristik Sifat Mekanik Bioplastik Pati Singkong/Pva Dengan Penambahan Pulp Tandan Kosong Kelapa Sawit Dan Asam Sitrat Teraktivasi." Jurnal Kimia Dan Kemasan $42 \quad$ (2): 46. https://doi.org/10.24817/jkk.v42i2.6130.

Widyaningsih, Senny., Kartika, Dwi., dan Nurhayati, Yuni. 2012. "Pengaruh Penambahan Sorbitol Dan Kalsium Karbonat Terhadap Karakteristik Dan Sifat Biodegradasi Film Dari Pati Kulit Pisang." Molekul 7 (1): 69-81.
Wijayanti, K., Dermawan, N., Faisah, S., Prayogi, V., Judiawan, W., Nugraha, T., dan Listryorini, N. 2016. "Bio-Degradeable Bioplastics Sebagai Plastik Ramah Lingkungan." Surya Octagon Interdisciplinary Journal of Technology 1 (2): 131-53.

Winarno, F., dan Fernandez, Ivone. 2010. Nanoteknologi Bagi Industri Pangan Dan Kemasan. Bogor: M-BRIO Press.

Yulianto, Putri, D. N., Perdani, M. S., Arbianti, R., Suryanegara, L., \& Hermansyah, H. 2020. "Effect Of Cellulose Fiber From Sorghum Bagasse On The Mechanical Properties And Biodegradability Of Polylactic Acid." Energy Reports 6 (1): 221-26.

Zakuwan, S.Z., Ahmad, I. 2018. "Synergetic Effect of Hybridized Cellulose Nanocrystals and Organically Modified Montmorillonite on K-Carrageenan Nanomaterials 8: 1-14. 